\title{
Association analysis of novel SNPs in exon 10 of the growth hormone receptor gene with growth traits in Indian sheep
}

\author{
Amiya R. Sahu ${ }^{1 *}$, Veerasamy Jeichitra ${ }^{2}$, Ramanujam Rajendran ${ }^{2}$, and Angamuthu Raja ${ }^{3}$ \\ ${ }^{1}$ Animal Genetics and Breeding, ICAR-Central Coastal Agricultural Research Institute, Goa, India \\ ${ }^{2}$ Post Graduate Research Institute in Animal Sciences, Kattupakkam, Kancheepuram, T.N., India \\ ${ }^{3}$ Department of Animal Biotechnology, Madras Veterinary College, T.N., India
}

SAHU, A. R., V. JEICHITRA, R. RAJENDRAN, A. RAJA: Association analysis of novel SNPs in exon 10 of the growth hormone receptor gene with growth traits in Indian sheep. Vet. arhiv 90, 593-602, 2020.

\section{ABSTRACT}

The growth hormone receptor (GHR) gene encodes the type I cytokine receptor that helps in joining the growth hormone to this receptor, thus promoting receptor-dimerization, leading to up-regulating growth. The ovine GHR gene located on chromosome 16, which consists of 10 exons and 9 introns, along with untranslated regions on either side, comprise a total size of $178.09 \mathrm{~kb}$. However, earlier reports about polymorphism have mainly dealt with exon 10 which is also a larger fragment of this gene comprising $1102 \mathrm{bp}$. Hence, this study was carried out to detect polymorphism in exon 10 of the GHR gene and its association with growth traits. Genomic DNA was isolated from blood samples of Madras Red and Mecheri sheep breeds from India. Part of exon 10 (895 bp) of the GHR gene was amplified and sent for sequencing. The sequence analysis revealed transition of nucleotide G $>$ A at loci G177624A and G177878A in both sheep breeds. Populations were screened by Tetra-primer ARMS-PCR. The genotype frequencies of $G G, G A$ and $A A$ were $0.276,0.519$ and 0.205 at $177624 \mathrm{G}>\mathrm{A}$, and $0.307,0.444$ and 0.149 at $177878 \mathrm{G}>\mathrm{A}$ in Madras Red sheep; whereas in Mecheri they were $0.476,0.372$ and 0.152 at $177624 \mathrm{G}>\mathrm{A}$, and $0.629,0.314$ and 0.057 at 177878 $\mathrm{G}>\mathrm{A}$, respectively. Likewise the estimated allele frequencies of $G$ and $A$ were 0.5355 and 0.4645 at $177624 \mathrm{G}>\mathrm{A}$, and 0.5790 and 0.4210 at $177878 \mathrm{G}>\mathrm{A}$ in Madras Red sheep; whereas in Mecheri they were 0.6620 and 0.3380 at 177624 $\mathrm{G}>\mathrm{A}$, and 0.7860 and 0.2140 at $177878 \mathrm{G}>\mathrm{A}$, respectively. The effect of sex was significant for birth, six and nine month weight; but non-significant for three and 12 month weight in Mecheri sheep. However, in the Madras Red breed the effect of sex was significant for all body weights except weaning weight. The effect of variations on growth traits, viz., birth weight, weight at weaning, and weight at six, nine and twelve months in both breeds were analysed for their association, and they were found non-significant. Since these SNPs are salient findings of GHR gene polymorphism in Indian sheep breeds, further investigation is required into the significant effects of these novel SNPs, which could be useful for genetic improvement based on marker assisted selection.

Key words: association; body weights; growth hormone receptor gene; native sheep; SNP

\section{Introduction}

The sheep population is a major economic and ecological resource, predominantly serving humans in multiple aspects, providing proteinous

meat, woolly clothing, raising farmers' income, facilitating rural employment, and above all sheep improve soil fertility (DEVENDRA, 2001). Sheep

\footnotetext{
*Corresponding author:

Amiya Ranjan Sahu, Department of Animal Genetics and Breeding, Madras Veterinary College, Chennai, Tamil Nadu, India, E-mail: dramiyavet@, gmail.com
} 
farming is one of the most developed sectors, comprising $12.7 \%$ of the total livestock population. India has 43 sheep breeds, numbering 65.06 million heads (LIVESTOCK CENSUS REPORT, 2012). Annual mutton production in India is around $7.12 \%$, and 31,440 tonnes of mutton are produced by Tamil Nadu state of India alone from where the Madras Red and Mecheri sheep breeds studied originate, with 4.47 million sheep (ANON, 2015). The efficiency of sheep enterprises can be improved by increasing litter size, lamb weight, mutton production, and by the improvement of wool quality. DNA based molecular markers are used efficiently for assessment of genetic diversity, selection of animals at an early age, studying population structure, mapping of genes and quantitative trait loci (QTLs), and breeding based on genomic selection (COLLARD et al., 2005). Genomic selection in the livestock industries has been made possible by the availability of high density single nucleotide polymorphism (SNP) marker panels, commonly referred to as "SNP chips" (ZHANG et al., 2012). Genetic analysis of organisms has been revolutionized by recombinant DNA technology, DNA sequencing, and application of markerassisted selection in contrast to traditional methods of selection (WAKCHAURE et al., 2015). Genome maps contain assignments of markers and genes to specific regions along the chromosomes, which are useful for organizing systematic searches for the chromosome regions containing important genes. Around 200 equally spaced markers are required to entirely scan the genome of a livestock species (MORADI et al., 2012). Due to marker clustering, these markers are required to achieve adequate coverage of a 10 to 20 centimorgan genetic map. Additional markers are very essential to increase the resolution of the map, in order to proceed with the isolation of genes that are economically important and to apply molecular breeding strategies. The significant SNPs are used as molecular markers for genetic analysis, using them as long-term selection markers. These are also prevalent and provide more potential markers near or at any locus of interest, and some SNPs are located in coding regions which directly affect protein function (BEUZEN et al.,
2000). The relationship between the economic traits and the genes associated with these have been studied by the candidate gene approach (ANDERSSON, 2001). Marker Assisted Selection enables the unambiguous selection of specific nucleotide variations that are related to differences in growth and meat production traits (DEKKERS AND HOSPITAL, 2002). The growth hormone receptor $(G H R)$ is the major candidate gene situated on chromosome 16 in sheep (ARCHIBALD et al., 2010). It consists of 10 exons with 9 intervening regions, comprising exon 10 as the longest (1102 bp) regulatory sequence. Any allelic variation in the regulatory sequences of the growth hormone and its receptor genes affects body growth (MULLIS, 2011). Scanty reports are available on polymorphism of the GHR gene in exotic sheep (BASTOS et al., 2001; VALEH et al., 2009; BAHRAMI et al., 2013). In spite of the functional importance of $G H R$ in the regulation of growth hormone, there are few findings about the nucleotide variability of indigenous sheep and cattle breeds (SAHU et al., 2017; DEEPIKA ANDSALAR, 2013). Hence, this study was undertaken to find polymorphism in the exonic region and correlate associations with growth traits which may be affected due to single nucleotide polymorphism.

\section{Materials and methods}

Experimental animals. Madras Red and Mecheri are meat type breeds native to two different geographical regions of Tamil Nadu, India. Blood was collected from animals of both sexes of Madras Red $(n=127)$ from the Post Graduate Research Institute in Animal Sciences, Kattupakkam; and Mecheri $(n=105)$ from the Mecheri Sheep Research Station, Pottaneri, both being constituent units of Tamil Nadu Veterinary and Animal Sciences University, Tamil Nadu. The body weights of the animals at birth, pre-weaning, six, nine and twelve months of age were also recorded along with the corresponding dam's weight at lambing. Genomic DNA was isolated using the Phenol-Chloroform extraction method, with a slight change of the DNAzol reagent, instead of SDS and proteinase K (SAMBROOK et al., 1989). 
PCR programme. Primer pairs were designed by Fast PCR Primer designing software v. 3 (KALENDAR et al., 2014) to amplify part of exon 10 (895 bp) of the GHR gene. The reaction was performed in microfuge tubes $(0.2 \mathrm{~mL})$ using thermal cyclers (Eppendorf Mastercycler ep gradient S and Applied Biosystems 2720 models). The total of $20 \mu \mathrm{L}$ of reaction mixture comprised $10 \mu \mathrm{L}$ master mix, $0.8 \mu \mathrm{L}$ each of the forward (CCCTGATGAGAAGACTGAAGGGT) and reverse (TCAATGGGTAGCTCATGGGAA) primers $(10 \mathrm{pmol} / \mu \mathrm{L}), 1.5 \mu \mathrm{L}$ template DNA $(50$ $n g / \mu \mathrm{L}$ ) and $6.9 \mu \mathrm{L}$ of nuclease free water (SAHU et al., 2017). The amplification was performed in a thermal cycler for initial denaturation at $95{ }^{\circ} \mathrm{C}$ (5 $\mathrm{min}$ ), followed by 34 cycles of denaturation at $95{ }^{\circ} \mathrm{C}(35 \mathrm{sec})$, annealing at $60{ }^{\circ} \mathrm{C}(30 \mathrm{sec})$ and extension at $72{ }^{\circ} \mathrm{C}(35 \mathrm{sec})$, with final extension at $72{ }^{\circ} \mathrm{C}(5 \mathrm{~min})$, and ended at $4{ }^{\circ} \mathrm{C}$. PCR products were confirmed by agarose gel electrophoresis $(2 \%$ agarose) in $1 \mathrm{X} \mathrm{TAE}$, and visualized under UVillumination using the gel documentation system (Bio-Rad, Laboratories Inc., USA).
Analysis of sequence variations. Sixteen random samples (eight from each breed) were sequenced in both forward and reverse directions for $895 \mathrm{bp}$ amplicon using an ABI PRISM 3730XL Genetic analyzer (Applied Biosystems, USA). Sequence data were analyzed using the SeqMan program of LASERGENE software, version 7.1.0 (44) (DNASTAR Inc., USA). The sequences were assembled and screened for SNPs.

Screening the population. Populations of both breeds were genotyped according to the mutations identified with two pairs of primers (Table 1) designed by the online "Tetra-primer ARMS-PCR" designing software (YE et al., 2001). Amplification was performed for both GHR-177624 and GHR177878 primers (Table 2 and Table 3). Agarose electrophoresis was carried out for $60 \mathrm{~min}$ with $2.5 \%$ agarose in $1 \mathrm{X}$ TAE buffer, to confirm the products (AHLAWAT et al., 2013). The gene and genotype frequencies at each locus were calculated which signified population was under the Hardy-Weinberg equilibrium (FALCONER and MACKAY, 1996).

Table 1. Primers used in genotyping the population

\begin{tabular}{|c|c|c|c|}
\hline Sl. No. & Name of primer & Primers $(5 '-3$ ' end $)$ & Product size (bp) \\
\hline 1. & GHR-177624 & $\begin{array}{l}\text { Forward inner } \\
\text { AGA AGT GGT CAC ACC CAG CCA AGA AA } \\
\text { Reverse inner } \\
\text { AGA AGT AAG CGC TGT CCA CGA TGA ATT C } \\
\text { Forward outer } \\
\text { GCC AGC AGC CCA GTG TTA TCC TAG TAG A } \\
\text { Reverse outer } \\
\text { ACT TGG AAC ATT TTC TGC TGT CCC TGA C }\end{array}$ & $\begin{array}{l}A \text { allele }=209 \\
G \text { allele }=279 \\
\text { Outer }=434\end{array}$ \\
\hline 2. & GHR-177878 & $\begin{array}{l}\text { Forward inner } \\
\text { AGT CTC CAC AGG GCC TCG TAC TCA ATT CG } \\
\text { Reverse inner } \\
\text { CTT TGT CAG GCA AGG GCA GGG CAT TT } \\
\text { Forward outer } \\
\text { GGT CAC ACC CAG CCA AGC AGA CTT CAT C } \\
\text { Reverse outer } \\
\text { CAA CTC ATC CCC CTC CCC CAA AAA AGT T }\end{array}$ & $\begin{array}{l}A \text { allele }=299 \\
G \text { allele }=225 \\
\text { Outer }=469\end{array}$ \\
\hline
\end{tabular}


A. R. Sahu et al.: Association analysis of novel SNPs in exon 10 of the growth hormone receptor gene with growth traits in Indian sheep

Table 2. PCR reaction mixture for detected SNPs

\begin{tabular}{|l|l|c|c|}
\hline \multirow{2}{*}{ Sl. No. } & \multirow{2}{*}{ Components } & \multicolumn{2}{|c|}{ Volume $(\mu \mathrm{L})$} \\
\cline { 3 - 4 } & Master mix (Ampliqon) & GHR-177624 & GHR-177878 \\
\hline 1. & Forward Inner $(10 \mathrm{pmol} / \mu \mathrm{L})$ & 0.0 & 0.4 \\
\hline 2. & Reverse Inner $(10 \mathrm{pmol} / \mu \mathrm{L})$ & 0.3 & 0.4 \\
\hline & Forward Outer $(10 \mathrm{pmol} / \mu \mathrm{L})$ & 0.3 & 0.4 \\
\hline & Reverse Outer $(10 \mathrm{pmol} / \mu \mathrm{L})$ & 0.3 & 0.4 \\
\hline & Template DNA $(50 \mathrm{ng} / \mu \mathrm{L})$ & 1.0 & 2.2 \\
\hline 3. & Nuclease free water & 2.8 & 10.0 \\
\hline
\end{tabular}

Table 3. PCR protocol for genotyping through Tetra-primer ARMS-PCR

\begin{tabular}{|c|c|c|c|c|c|}
\hline \multirow[b]{2}{*}{ Step } & \multirow[b]{2}{*}{ Process } & \multicolumn{2}{|r|}{ GHR 177624} & \multicolumn{2}{|r|}{ GHR 177878} \\
\hline & & Temperature & Duration & Temperature & Duration \\
\hline 1 & Initial denaturation & $95^{\circ} \mathrm{C}$ & $5 \mathrm{~min}$ & $95^{\circ} \mathrm{C}$ & $5 \mathrm{~min}$ \\
\hline 2 & Denaturation: & $95^{\circ} \mathrm{C}$ & $35 \mathrm{sec}$ & $95^{\circ} \mathrm{C}$ & $35 \mathrm{sec}$ \\
\hline 3 & Annealing: & $61.5^{\circ} \mathrm{C}$ & $30 \mathrm{sec}$ & $59.5^{\circ} \mathrm{C}$ & $30 \mathrm{sec}$ \\
\hline 4 & Extension: & $72{ }^{\circ} \mathrm{C}$ & $35 \mathrm{sec}$ & $72{ }^{\circ} \mathrm{C}$ & $35 \mathrm{sec}$ \\
\hline 5 & Back to steps 2 to 4 & 34 cycles & 35 cycles & & \\
\hline 6 & Final extension & $72{ }^{\circ} \mathrm{C}$ & $5 \mathrm{~min}$ & $72{ }^{\circ} \mathrm{C}$ & $5 \mathrm{~min}$ \\
\hline 7 & Hold & $4^{\circ} \mathrm{C}$ & Until samples are removed & $4^{\circ} \mathrm{C}$ & Until samples are removed \\
\hline
\end{tabular}

Data analysis. The polymorphisms observed at both loci of the GHR gene in Madras Red and Mecheri breeds were analysed for their association with body weights at various ages viz., birth, weaning (three months), six, nine and twelve months weights, using least-squares procedures (HARVEY, 1990). The blood sample was collected for genotyping from 127 animals (27 males and 100 females) of Madras Red, and 105 animals (31 males and 54 females) of Mecheri breed. The number of animals used for association analysis in Madras Red was 22 males and 88 females $(\mathrm{n}=110)$ and in Mecheri 31 males and 54 females $(n=85)$, which is lower than the number of animals genotyped due to the unavailability of complete sets of data on body weight and deletion of outliers. The outliers in the data set correspond to the animals with extremely high and low body weights, which are definitely due to errors in recording. All data within the range of the body weights reported for the breed average were considered for analysis. The non-availability of grazing land leads to intensive feeding in Madras Red, whereas Mecheri sheep are allowed free ranging along with intensive feeding in their breeding tract.

The period was not partitioned or defined as the annual effect due to the limitation of population size, as only a small number of sheep is kept on the research farms. If the annual effect was assessed, the number would be so small that the least-squares analysis could not be performed. Secondly, the breeding rams were changed once in three or four years depending on the farm management practices. Considering these facts, the data set was classified into period effects. Data were classified into: two periods of birth: viz., $1^{\text {st }}$ (2007 to 2010) and $2^{\text {nd }}(2011$ to 2014) in Madras Red; and $1^{\text {st }}$ (2008 to 2010) and $2^{\text {nd }}$ (2011 to 2013) in Mecheri sheep; sex as males and females; and three different genotypes each at 
loci G177624A and G177878A of GHR gene. The weight of the dam at lambing was also considered as a covariable in the given model:

$$
\mathrm{Y}_{\mathrm{ijk} \mathrm{k}}=\mu+\mathrm{P}_{\mathrm{i}}+\mathrm{S}_{\mathrm{j}}+\mathrm{G}_{\mathrm{k}}+\mathrm{b}\left(\mathrm{WM}_{\mathrm{ij} \mathrm{k}}-\mathrm{WM}\right)+\mathrm{e}_{\mathrm{ijkl}}
$$

where:

$\mathrm{Y}_{\mathrm{ijk} \mathrm{k}}=$ body weight of the $\mathrm{l}^{\text {th }}$ animal of $\mathrm{k}^{\text {th }}$ genotype of $\mathrm{j}^{\text {th }}$ sex born in $\mathrm{i}^{\text {th }}$ period of lambing,

$\mu=$ overall mean,

$\mathrm{P}_{\mathrm{i}}=$ fixed effect of $\mathrm{i}^{\text {th }}$ period of lambing $(\mathrm{i}=1$ and 2$)$,

$\mathrm{S}_{\mathrm{j}}=$ fixed effect of $\mathrm{j}^{\text {th }}$ sex of the lamb $(\mathrm{j}=1$ for male and 2 for female),

$\mathrm{G}_{\mathrm{k}}=$ fixed effect of $\mathrm{k}^{\text {th }}$ genotype $(\mathrm{k}=1,2$ and 3 for loci G177624A and G177878A),

$\mathrm{b}\left(\mathrm{WM}_{\mathrm{ijk}}-\mathrm{WM}\right)=$ regression of $\mathrm{Y}$ on dam's weight at lambing,

$\mathrm{e}_{\mathrm{ijkl}}=$ residual random error, $\operatorname{NID}\left(0, \sigma^{2}\right)$.

\section{Results and discussion}

The amplified fragment of exon 10 showed transitions of nucleotide $\mathrm{G}>\mathrm{A}$ at $\mathrm{G} 177624 \mathrm{~A}$ and G177878A were indicated in the chromatogram (Fig. 1 and Fig. 2) in both the sheep breeds studied (GenBank Accession No. KT757901and KT781164). The nucleotide variability at locus G177624A revealed a change of amino acid aspartic acid (GAC) to aspargine (AAC).

Genotyping was carried out for the locus 177624. G>A yielded amplified products of 209 bp, 279 bp and 434 bp; where: $G G=279$ bp and $434 \mathrm{bp} ; A A=209 \mathrm{bp}$ and $434 \mathrm{bp}$; and $G A=209$ bp, 279 bp and 434 bp (Fig. 3). All three genotypes were observed in both breeds. Genotypic and allelic frequencies were determined in both breeds and are presented in Table 4. The observed genotype frequencies of $G G, G A$ and $A A$ were $0.276,0.519$ and 0.205 in Madras Red and 0.476, 0.372 and 0.152 in Mecheri breeds. The estimated frequencies of $G$ and $A$ alleles were 0.5355 and 0.4645 ; and 0.6620 and 0.3380 in Madras Red and Mecheri, respectively. The population of both breeds was in genetic equilibrium, with a higher frequency of $G$ than $A$.

The size of amplified products obtained for locus $177878 \mathrm{G}>\mathrm{A}$ was $225 \mathrm{bp}, 299 \mathrm{bp}$ and 469 bp; where: $G G=225$ bp and $469 \mathrm{bp} ; A A=299 \mathrm{bp}$ and $469 \mathrm{bp}$; and $G A=225 \mathrm{bp}, 299 \mathrm{bp}$ and $469 \mathrm{bp}$ (Fig. 4). Genotypic and allelic frequencies at this locus are presented for both sheep breeds (Table 4). The observed genotypic frequencies of $G G, G A$ and $A A$ were 0.307, 0.544 and 0.149 ; and 0.629, 0.314 and 0.057 in Madras Red and Mecheri breeds, respectively. The estimated frequencies of $G$ and $A$ alleles were 0.5790 and 0.4210 in Madras Red, while in Mecheri sheep breed they were 0.7860 and 0.2140 , respectively, indicating a higher frequency of $\mathrm{G}$ than A allele. The populations of both sheep breeds at locus $177878 \mathrm{G}>\mathrm{A}$ were in equilibrium due to a non-significant $\chi^{2}$ value $(\mathrm{P}>0.05)$.

The heterozygote frequency of both loci observed was higher in Madras Red sheep and was comparable to the findings of Baluchi sheep (VALEH et al., 2009) and Nilagiri sheep (SAHU et al., 2017). Despite the mutations detected, monomorphism has been reported in exon 10 in Indian sheep breeds (SAHU et al., 2016), as well as in other regions of the GHR gene in exotic sheep breeds (BASTOS et al., 2001; BAHRAMI et al., 2013; SHIRI et al., 2006; MAHROUS et al., 2014).

Association of novel mutations with growth traits. The least square means for body weights at various ages, viz., birth, weaning, six, nine and 12 months in both Madras Red and Mecheri sheep breeds, are presented in Table 5 and 6 . The effect of sex was significant for birth, six and nine months weight; whereas it was non-significant for three and 12 months weight in Mecheri sheep. However, in the Madras Red breed the effect of sex was significant for all body weights, except weaning weight. The polymorphic effect at both the loci G177624A andG177878A on body weight at various ages, viz., birth, weaning, six, nine and twelve months body weight, were determined to be non-significant in both Madras Red and Mecheri sheep breeds (Table 7 and Table 8).

The non-significant effect of the nucleotide variability of the GHR gene on growth traits in both breeds of sheep was similar to the research findings in Baluchi sheep (VALEH et al., 2009) and Nilagiri (SAHU et al., 2017). The non-significant effect may possibly be due to the closed flock and small sample size. Further, the single nucleotide polymorphisms recognized may not be a significant major factor for body weights, as all the quantitative traits are controlled by many genes. 
A. R. Sahu et al.: Association analysis of novel SNPs in exon 10 of the growth hormone receptor gene with growth traits in Indian sheep

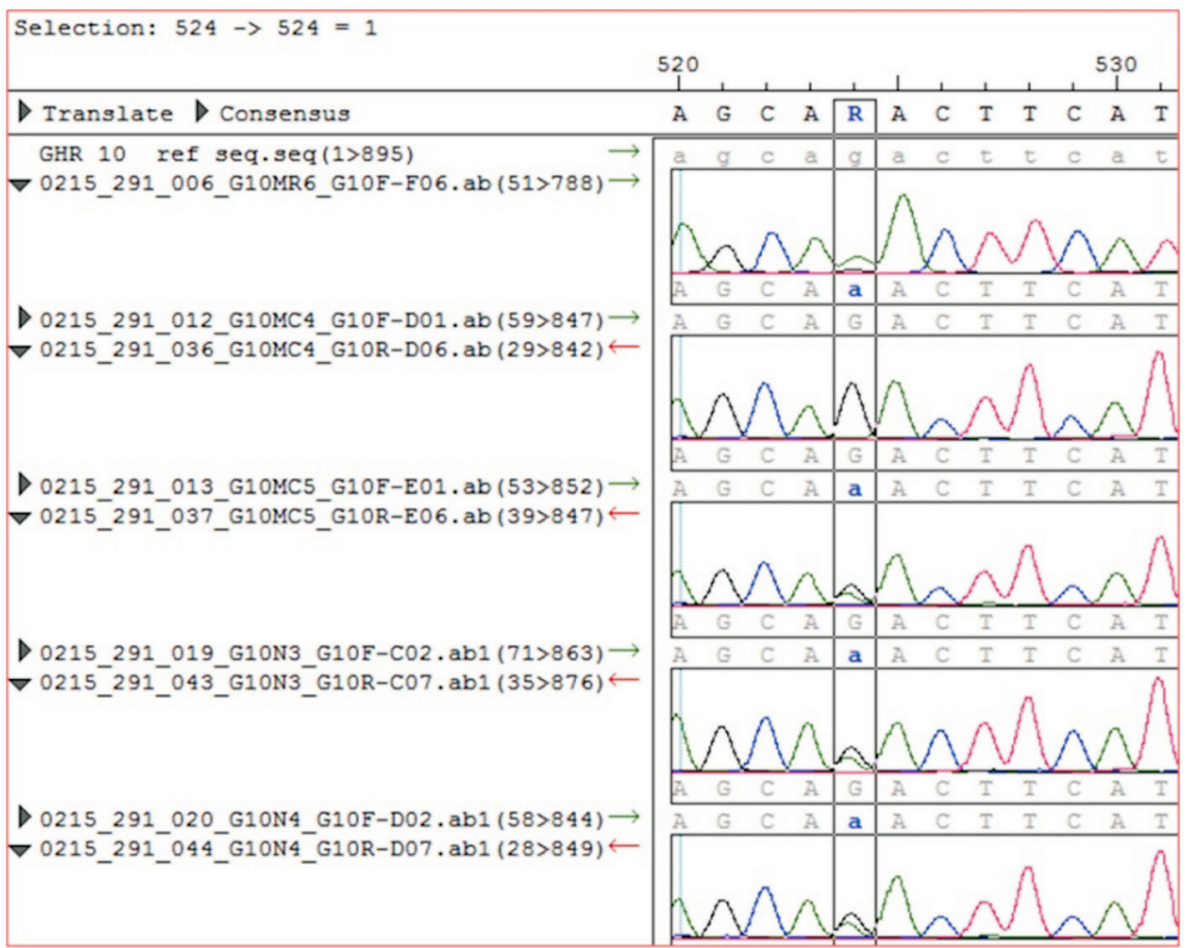

Fig. 1. Polymorphism at locus G177624A in exon 10 of the GHR gene in Madras Red and Mecheri sheep

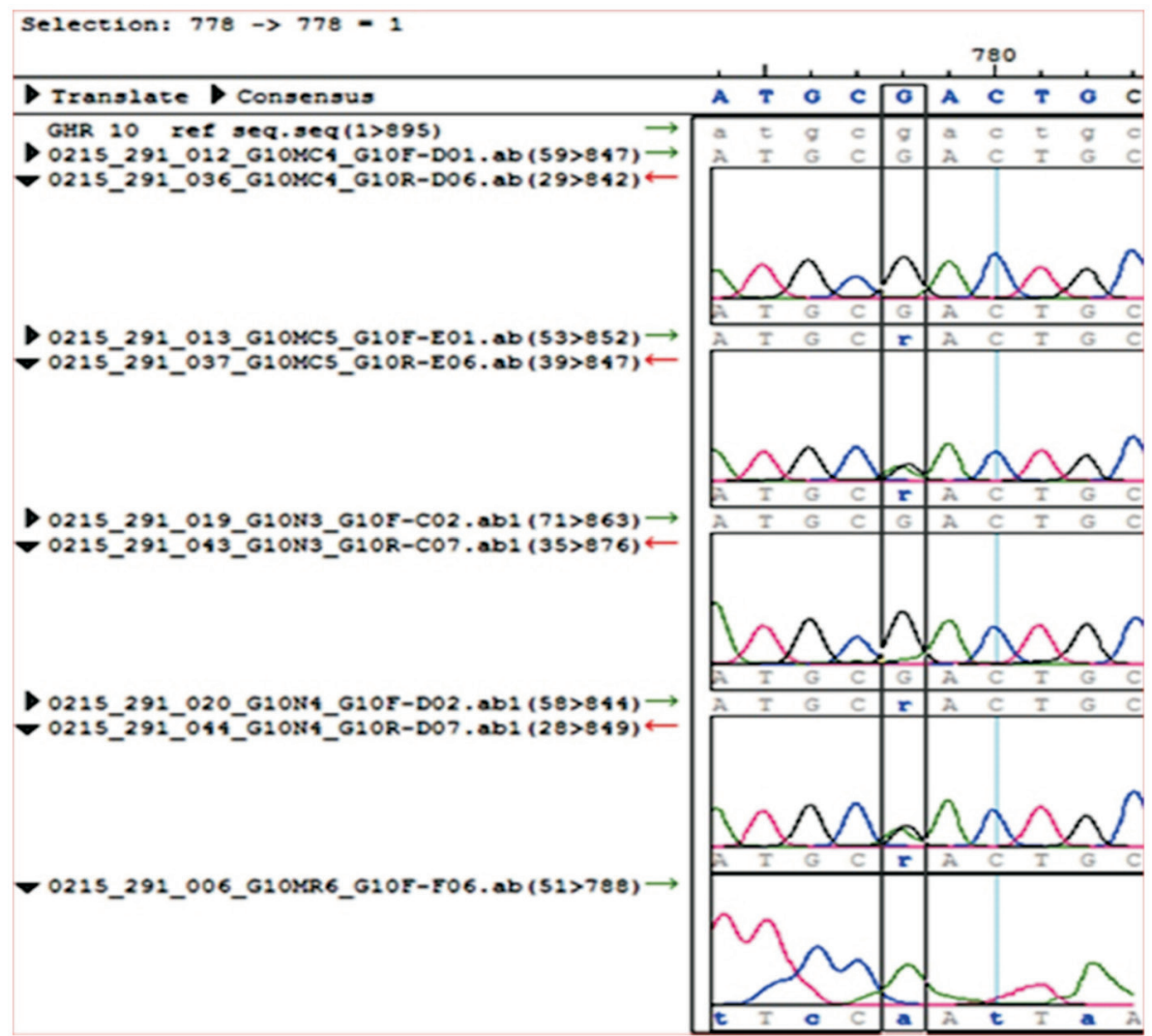

Fig. 2. Polymorphism at locus G177878A in exon 10 of the GHR gene in Madras Red and Mecheri sheep 


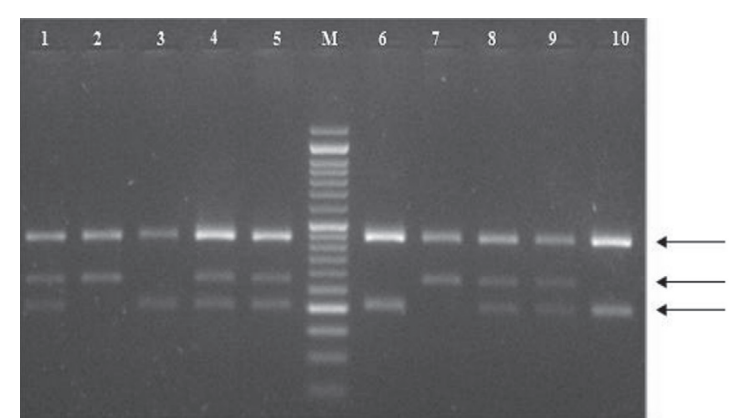

Fig. 3. Genotyping by Tetra-primer ARMS-PCR for locus $177624 \mathrm{G}>\mathrm{A}$. Lane $\mathrm{M}$ - 50 bp DNA ladder; Lanes 1, 4, 5, 8 and 9 - GA (209 bp, 279 bp and 434 bp); 3, 6 and 10 - AA (209 bp and 434 bp); and 2 and 7 - GG (279 bp and 434 bp); Lanes 1 to 5 Madras Red; and 6 to 10 Mecheri sheep

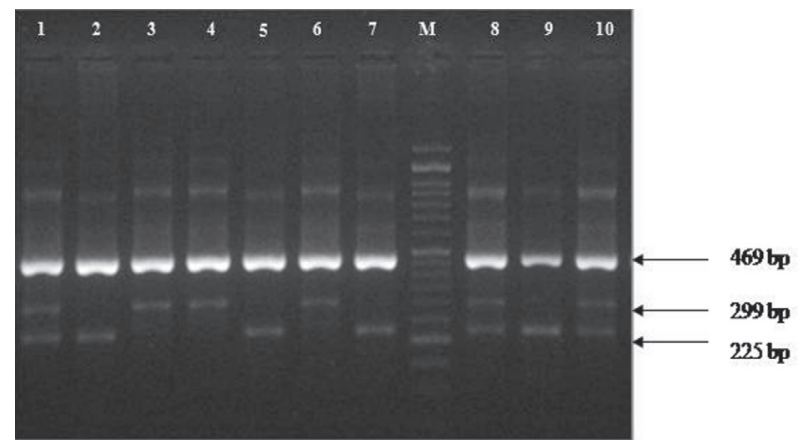

Fig. 4. Genotyping by Tetra-primer ARMS-PCR for locus $177878 \mathrm{G}>\mathrm{A}$. Lane M - 50 bp DNA ladder; Lanes 1, 8 and 10 - GA (225 bp, 299 bp and 469 bp); 2, 5, 7 and 9 - GG (225 bp and 469 bp); and 3, 4 and 6 - AA (299 bp and 469bp); Lanes 1 to 5 Madras Red; and 6 to 10 Mecheri sheep

Table 4. Mutations at loci $177624 \mathrm{G}>\mathrm{A}$ and $177878 \mathrm{G}>\mathrm{A}$ in exon 10 of $G H R$ gene

\begin{tabular}{|c|c|c|c|c|c|}
\hline SNP & Breed & Genotype & $\begin{array}{l}\text { Genotypic } \\
\text { frequency }\end{array}$ & Allelic frequency & $\chi^{2}$ value \\
\hline \multirow{2}{*}{$177624 \mathrm{G}>\mathrm{A}$} & Madras Red (127) & $\begin{array}{l}\text { GG (35) } \\
\text { GA (66) } \\
\text { AA (26) }\end{array}$ & $\begin{array}{l}0.276 \\
0.519 \\
0.205\end{array}$ & $\begin{array}{l}G=0.5355 \\
A=0.4645\end{array}$ & $0.25^{\mathrm{NS}}$ \\
\hline & Mecheri (105) & $\begin{array}{l}\text { GG (50) } \\
\text { GA (39) } \\
\text { AA (16) }\end{array}$ & $\begin{array}{l}0.476 \\
0.372 \\
0.152 \\
\end{array}$ & $\begin{array}{l}G=0.6620 \\
A=0.3380\end{array}$ & $3.03^{\mathrm{NS}}$ \\
\hline \multirow{2}{*}{$177878 \mathrm{G}>\mathrm{A}$} & Madras Red (127) & $\begin{array}{l}\text { GG (39) } \\
\text { GA (69) } \\
\text { AA (19) }\end{array}$ & $\begin{array}{l}0.307 \\
0.544 \\
0.149\end{array}$ & $\begin{array}{l}\mathrm{G}=0.5790 \\
\mathrm{~A}=0.4210\end{array}$ & $1.65^{\mathrm{NS}}$ \\
\hline & Mecheri (105) & $\begin{array}{c}\text { GG (66) } \\
\text { GA (33) } \\
\text { AA (6) }\end{array}$ & $\begin{array}{l}0.629 \\
0.314 \\
0.057\end{array}$ & $\begin{aligned} \mathrm{G} & =0.7860 \\
\mathrm{~A} & =0.2140\end{aligned}$ & $0.46^{\mathrm{NS}}$ \\
\hline
\end{tabular}

Figures in parentheses indicate number of observations; ${ }^{\text {NS }}$ - not significant

Table 5. Least-squares means ( $\pm \mathrm{SE}$ ) of body weights $(\mathrm{kg})$ of Madras Red sheep at different ages

\begin{tabular}{|c|c|c|c|c|c|}
\hline \multirow[b]{2}{*}{ Main effect } & \multicolumn{5}{|c|}{ Body weight at } \\
\hline & Birth & 3 months & 6 months & 9 months & 12 months \\
\hline Overall mean & $\begin{array}{c}2.728 \pm 0.053 \\
(110)\end{array}$ & $\begin{array}{c}9.158 \pm 0.348 \\
(110)\end{array}$ & $\begin{array}{c}13.410 \pm 0.350 \\
(110)\end{array}$ & $\begin{array}{c}17.014 \pm 0.448 \\
(110)\end{array}$ & $\begin{array}{c}19.052 \pm 0.473 \\
(110)\end{array}$ \\
\hline Sex of lamb & $*$ & NS & $* *$ & $* *$ & $* *$ \\
\hline Male & $\begin{array}{c}2.811^{\mathrm{b}} \pm 0.085 \\
(22)\end{array}$ & $\begin{array}{c}9.397 \pm 0.556 \\
(22)\end{array}$ & $\begin{array}{c}14.562^{\mathrm{b}} \pm 0.559 \\
(22)\end{array}$ & $\begin{array}{c}18.575^{\mathrm{b}} \pm 0.715 \\
(22)\end{array}$ & $\begin{array}{c}21.270^{\mathrm{b}} \pm 0.754 \\
(22)\end{array}$ \\
\hline Female & $\begin{array}{c}2.645^{\mathrm{a}} \pm 0.044 \\
(88)\end{array}$ & $\begin{array}{c}8.920 \pm 0.288 \\
(88)\end{array}$ & $\begin{array}{c}12.259^{\mathrm{a}} \pm 0.289 \\
(88)\end{array}$ & $\begin{array}{c}15.452^{\mathrm{a}} \pm 0.370 \\
(88)\end{array}$ & $\begin{array}{c}16.833^{\mathrm{a}} \pm 0.390 \\
(88)\end{array}$ \\
\hline Prob. & 0.0482 & 0.3836 & 0.0001 & 0.0001 & 0.0001 \\
\hline
\end{tabular}

Figures in parentheses are the number of observations; Means with at least one common superscript within classes do not differ significantly; * - P $\geq 0.05$ 
A. R. Sahu et al.: Association analysis of novel SNPs in exon 10 of the growth hormone receptor gene with growth traits in Indian sheep

Table 6. Least-squares means ( \pm SE) of body weights $(\mathrm{kg})$ of Mecheri sheep at different ages

\begin{tabular}{|c|c|c|c|c|c|}
\hline \multirow[b]{2}{*}{ Main effect } & \multicolumn{5}{|c|}{ Body weight at } \\
\hline & Birth & 3 months & 6 months & 9 months & 12 months \\
\hline Overall mean & $\begin{array}{c}2.531 \pm 0.062 \\
(85)\end{array}$ & $\begin{array}{c}12.623 \pm 0.413 \\
(85)\end{array}$ & $\begin{array}{c}14.791 \pm 0.454 \\
(85)\end{array}$ & $\begin{array}{c}17.411 \pm 0.520 \\
(85)\end{array}$ & $\begin{array}{c}19.671 \pm 0.587 \\
(85)\end{array}$ \\
\hline Sex of lamb & $*$ & $\mathrm{NS}$ & $*$ & $*$ & NS \\
\hline Male & $\begin{array}{c}2.627^{b} \pm 0.083 \\
(31)\end{array}$ & $\begin{array}{c}13.148 \pm 0.554 \\
\text { (31) }\end{array}$ & $\begin{array}{c}15.457^{\mathrm{b}} \pm 0.609 \\
\text { (31) }\end{array}$ & $\begin{array}{c}18.210^{\mathrm{b}} \pm 0.697 \\
(31)\end{array}$ & $\begin{array}{c}20.021 \pm 0.787 \\
\text { (31) }\end{array}$ \\
\hline Female & $\begin{array}{c}2.434^{\mathrm{a}} \pm 0.065 \\
(54)\end{array}$ & $\begin{array}{c}12.098 \pm 0.434 \\
(54)\end{array}$ & $\begin{array}{c}14.124^{\mathrm{a}} \pm 0.477 \\
(54)\end{array}$ & $\begin{array}{c}16.611^{\mathrm{a}} \pm 0.546 \\
(54)\end{array}$ & $\begin{array}{c}19.321 \pm 0.616 \\
(54)\end{array}$ \\
\hline Prob. & 0.0226 & 0.0622 & 0.0320 & 0.0248 & 0.3772 \\
\hline
\end{tabular}

Figures in parentheses are the number of observations; Means with at least one common superscript within classes do not differ significantly; * - P $\geq 0.05$

Table 7. Least-squares means $\pm \mathrm{SE}(\mathrm{kg})$ of locus $177624 \mathrm{G}>\mathrm{A}$ in $G H R$ gene associated with growth traits

\begin{tabular}{|c|c|c|c|c|c|c|c|c|}
\hline \multirow[b]{2}{*}{ Traits } & \multicolumn{4}{|c|}{ Madras Red (110) } & \multicolumn{4}{|c|}{ Mecheri (85) } \\
\hline & $A A(22)$ & $A G(57)$ & $G G(31)$ & Prob. & $A A(11)$ & $A G(\underline{32})$ & $G G(\underline{42})$ & Prob. \\
\hline $\begin{array}{l}\text { Birth } \\
\text { weight }^{\text {NS }}\end{array}$ & $\begin{array}{c}2.689 \\
\pm 0.082 \\
\end{array}$ & $\begin{array}{c}2.743 \\
\pm 0.064 \\
\end{array}$ & $\begin{array}{c}2.751 \\
\pm 0.072 \\
\end{array}$ & 0.7861 & $\begin{array}{c}2.569 \\
\pm 0.107 \\
\end{array}$ & $\begin{array}{c}2.509 \\
\pm 0.092 \\
\end{array}$ & $\begin{array}{c}2.514 \\
\pm 0.095\end{array}$ & 0.9189 \\
\hline $\begin{array}{l}\text { Weaning } \\
\text { weight }^{\text {NS }}\end{array}$ & $\begin{array}{c}8.745 \\
\pm 0.535 \\
\end{array}$ & $\begin{array}{r}9.246 \\
\pm 0.417 \\
\end{array}$ & $\begin{array}{c}9.484 \\
\pm 0.475 \\
\end{array}$ & 0.4946 & $\begin{array}{c}12.932 \\
\pm 0.714\end{array}$ & $\begin{array}{l}12.345 \\
\pm 0.615 \\
\end{array}$ & $\begin{array}{c}12.592 \\
\pm 0.633 \\
\end{array}$ & 0.8080 \\
\hline $\begin{array}{l}6 \text { months } \\
\text { weight }^{\mathrm{NS}}\end{array}$ & $\begin{array}{l}13.440 \\
\pm 0.538\end{array}$ & $\begin{array}{l}13.469 \\
\pm 0.419\end{array}$ & $\begin{array}{l}13.321 \\
\pm 0.477 \\
\end{array}$ & 0.9561 & $\begin{array}{l}15.706 \\
\pm 0.786 \\
\end{array}$ & $\begin{array}{l}13.900 \\
\pm 0.677 \\
\end{array}$ & $\begin{array}{l}14.767 \\
\pm 0.696 \\
\end{array}$ & 0.1702 \\
\hline $\begin{array}{l}9 \text { months } \\
\text { weight }^{N S}\end{array}$ & $\begin{array}{l}17.478 \\
\pm 0.689 \\
\end{array}$ & $\begin{array}{l}16.857 \\
\pm 0.537\end{array}$ & $\begin{array}{l}16.706 \\
\pm 0.611\end{array}$ & 0.6068 & $\begin{array}{l}17.589 \\
\pm 0.899\end{array}$ & $\begin{array}{c}16.885 \\
\pm 0.774\end{array}$ & $\begin{array}{l}17.758 \\
\pm 0.797 \\
\end{array}$ & 0.4870 \\
\hline $\begin{array}{l}12 \text { months }^{\text {moight }} \\
\text { weigh }^{\text {NS }}\end{array}$ & $\begin{array}{l}18.913 \\
\pm 0.726\end{array}$ & $\begin{array}{l}19.091 \\
\pm 0.566\end{array}$ & $\begin{array}{l}19.151 \\
\pm 0.644\end{array}$ & 0.9597 & $\begin{array}{l}20.408 \\
\pm 1.015\end{array}$ & $\begin{array}{l}19.240 \\
\pm 0.874\end{array}$ & $\begin{array}{l}19.364 \\
\pm 0.899\end{array}$ & 0.7056 \\
\hline
\end{tabular}

Figures in parentheses indicate number of records used for analysis; ${ }^{\text {NS }}$ - not significant

Table 8. Least-squares means $\pm \mathrm{SE}(\mathrm{kg})$ of locus $177878 \mathrm{G}>\mathrm{A}$ in $G H R$ gene associated with growth traits

\begin{tabular}{|c|c|c|c|c|c|c|c|c|}
\hline \multirow[b]{2}{*}{ Traits } & \multicolumn{4}{|c|}{ Madras Red (110) } & \multicolumn{4}{|c|}{ Mecheri (85) } \\
\hline & $A A(18)$ & $A G(61)$ & $G G(31)$ & Prob. & $A A(5)$ & $A G(26)$ & $G G(54)$ & Prob. \\
\hline $\begin{array}{l}\text { Birth } \\
\text { weight }^{N S}\end{array}$ & $\begin{array}{c}2.711 \\
\pm 0.102\end{array}$ & $\begin{array}{c}2.752 \\
\pm 0.075\end{array}$ & $\begin{array}{c}2.754 \\
\pm 0.081\end{array}$ & 0.9217 & $\begin{array}{c}2.272 \\
\pm 0.176\end{array}$ & $\begin{array}{l}2.601 \\
\pm 0.077\end{array}$ & $\begin{array}{c}2.719 \\
\pm 0.076\end{array}$ & 0.0950 \\
\hline $\begin{array}{l}\text { Weaning } \\
\text { weight }^{\text {NS }}\end{array}$ & $\begin{array}{l}8.392 \\
\pm 0.611\end{array}$ & $\begin{array}{l}9.355 \\
\pm 0.451\end{array}$ & $\begin{array}{c}9.511 \\
\pm 0.483\end{array}$ & 0.2567 & $\begin{array}{l}12.596 \\
\pm 1.175\end{array}$ & $\begin{array}{l}12.083 \\
\pm 0.514\end{array}$ & $\begin{array}{l}13.190 \\
\pm 0.505\end{array}$ & 0.2104 \\
\hline $\begin{array}{l}6 \text { months } \\
\text { weight }\end{array}$ & $\begin{array}{l}13.779 \\
\pm 0.613\end{array}$ & $\begin{array}{l}13.412 \\
\pm 0.452\end{array}$ & $\begin{array}{l}13.190 \\
\pm 0.485\end{array}$ & 0.7270 & $\begin{array}{l}13.241 \\
\pm 1.293\end{array}$ & $\begin{array}{l}15.000 \\
\pm 0.566\end{array}$ & $\begin{array}{l}16.131 \\
\pm 0.556\end{array}$ & 0.1011 \\
\hline $\begin{array}{l}9 \text { months } \\
\text { weight }^{\text {Ns }}\end{array}$ & $\begin{array}{l}17.406 \\
\pm 0.797\end{array}$ & $\begin{array}{l}17.131 \\
\pm 0.588\end{array}$ & $\begin{array}{l}16.550 \\
\pm 0.631\end{array}$ & 0.6263 & $\begin{array}{l}15.493 \\
\pm 1.479\end{array}$ & $\begin{array}{l}18.204 \\
\pm 0.647\end{array}$ & $\begin{array}{l}18.534 \\
\pm 0.636\end{array}$ & 0.2327 \\
\hline $\begin{array}{l}12 \\
\text { months } \\
\text { weight }^{\mathrm{NS}}\end{array}$ & $\begin{array}{l}18.615 \\
\pm 0.825\end{array}$ & $\begin{array}{l}19.552 \\
\pm 0.609\end{array}$ & $\begin{array}{l}18.832 \\
\pm 0.653\end{array}$ & 0.4290 & $\begin{array}{l}17.574 \\
\pm 1.669\end{array}$ & $\begin{array}{l}20.421 \\
\pm 0.730\end{array}$ & $\begin{array}{l}21.018 \\
\pm 0.718\end{array}$ & 0.2306 \\
\hline
\end{tabular}

Figures in parentheses indicate number of records used for analysis; ${ }^{\mathrm{NS}}$ - not significant. 
A. R. Sahu et al.: Association analysis of novel SNPs in exon 10 of the growth hormone receptor gene with growth traits in Indian sheep

\section{Conclusions}

The growth hormone receptor $(G H R)$ gene was investigated to characterize the variations in part of exon 10 and exhibit their allelic status in Madras Red and Mecheri sheep in Tamil Nadu, India. The SNPs177624 G>A and $177878 \mathrm{G}>\mathrm{A}$ had no significant association with body weights at birth, weaning (three months), six, nine and twelve months of age. However, since this is the first report of GHR polymorphism in Indian sheep breeds, further research on variations and their effect on growth traits is required for them to be used as markers for genetic improvement through molecular breeding.

\section{Acknowledgments}

Authors are thankful to the authority in-charge of the PostGraduate Research Institute in Animal Sciences (PGRIAS), Kattupakkam and Mecheri Sheep Research Station (MSRS), Pottaneri for their invaluable support to execute this research work.

\section{References}

AHLAWAT, S., R. SHARMA, A. MITRA (2013): Screening of indigenous goats for prolificacy associated DNA markers of sheep. Gene 517, 128-134.

DOI: $10.1016 /$ j.gene.2012.12.015

ANDERSSON, L. (2001): Genetic dissection of phenotypic diversity in farm animals. Nature Rev. Genet. 2, 130-138.

DOI: $10.1038 / 35052563$

ANONYMOUS (2015): http://www.nbagr.res.in/current news/ newbreeds.pdf.

ARCHIBALD, A. L., N. E. COCKETT, B. P. DALRYMPLE, T. FARAUT, J. W. KIJAS, J. F. MADDOX, J. C. MCEWAN, V. HUTTON ODDY, H. W. RAADSMA, C. WADE, J. WANG, W. WANG, X. XUN (2010): The sheep genome reference sequence: a work in progress. Anim. Genet. 41, 449-453.

DOI: $10.1111 /$ j.1365-2052.2010.02100.x

BAHRAMI, A., S. H. BEHZADI, S. R. MIRAEI-ASHTIANI, S. G. ROH, K. KATOH (2013): Genetic polymorphisms and protein structures in growth hormone, growth hormone receptor, ghrelin, insulin-like growth factor 1 and leptin in Mehraban sheep. Gene 527, 397-404.

DOI: 10.1016/j.gene.2013.05.066

BASTOS, E., A. CRAVADOR, G. AZEVEDO, H. GUEDESPINTO (2001): Single strand conformation polymorphism (SSCP) detection in six genes in Portuguese indigenous sheep breed "Churra da Terra Quente". Biotechnol. Agron. Soc. Environ. 5, 7-15.
BEUZEN, N. D., M. J. STEAR, K. C. CHANG (2000): Molecular markers and their use in animal breeding. Vet. J. $160,42-52$.

DOI: $10.1053 /$ tvj1.2000.0468

COLLARD, B. C. Y., M. Z. Z. JAHUFER, J. B. BROUWER, E. C. K. PANG (2005): An introduction to markers, quantitative trait loci (QTL) mapping and marker-assisted selection for crop improvement: The basic concepts. Euphytica 142, 169-196.

DOI: $10.1007 / \mathrm{s} 10681-005-1681-5$

DEEPIKA, R. K. SALAR (2013): Polymorphism studies of Growth Hormone Receptor (GHR) gene in indigenous grey cattle breeds of India. DHR Int. J. Bio-med. Life Sci. 4, 270-277.

DEKKERS, J. C. M., F. HOSPITAL (2002): The use of molecular genetics in improvement of agricultural populations. Nature Rev. Genet. 3, 22-32.

DOI: $10.1038 / \mathrm{nrg} 701$

DEVENDRA, C. (2001): Small ruminants: Imperatives for productivity enhancement improved livelihood and rural growth - A review. Asian-Australas. J. Anim. Sci. 14, 14831496.

DOI: 10.5713/ajas.2001.1483

FALCONER, D. S., T. F. C. MACKAY (1996): Introduction to Quantitative Genetics ( $4^{\text {th }}$ ed.). Longman Group Limited, England.

HARVEY, W. R. (1990): Mixed Model Least-squares and Maximum Likelihood Computer Programme. PC-2 version. Ohio State University, Colombus.

KALENDAR, R., D. LEE, A. H. SCHULMAN (2014): FastPCR software for PCR, in silico PCR, and oligonucleotide assembly and analysis. DNA Cloning and Assembly Methods. Methods in Molecular Biology (Svein V., R. Lale, Eds.), Humana Press. 1116, 271-302.

DOI: $10.1007 / 978-1-62703-764-8 \_18$

LIVESTOCK CENSUS REPORT (2012): Department of Animal Husbandry and Dairying, Ministry of Agriculture, Government of India, New Delhi.

MAHROUS, K. F., N. M. SABRY, N. H. ALTWATY, L. M. SALEM (2014): Molecular comparative study of growth hormone receptor (GHR) gene in Egyptian and Saudi breeds of sheep (Ovis aries). Int. J. Adv. Res. 2, 1102-1111.

MORADI, M. H., NEJATI-JAVAREMI, A., MORADISHAHRBABAK, M., DODDS, K. G., MCEWAN, J. C. (2012). Genomic scan of selective sweeps in thin and fat tail sheep breeds for identifying of candidate regions associated with fat deposition. BMC Genet. 13, 1-15.

DOI: 10.1186/1471-2156-13-10

MULLIS, P. E. (2011): Genetics of GHRH, GHRH-receptor, $\mathrm{GH}$ and GH-receptor: its impact on pharmacogenetics. Best Pract. Res. Clin. Endocrinol. Metab. 25, 25-41.

DOI: 10.1016/j.beem.2010.06.006 
A. R. Sahu et al.: Association analysis of novel SNPs in exon 10 of the growth hormone receptor gene with growth traits in Indian sheep

SAHU, A. R., V. JEICHITRA, R. RAJENDRAN, A. RAJA (2017): Polymorphism of growth hormone receptor (GHR) gene in Nilagiri sheep. Trop. Anim. Health Prod. 49, 281285.

DOI: $10.1007 / \mathrm{s} 11250-016-1189-0$

SAHU, A. R., V. JEICHITRA, R. RAJENDRAN, A. RAJA, S. N. SIVASELVAM, S. M. K. KARTHICKEYAN (2016): Monomorphism of growth hormone receptor gene in south Indian breeds of sheep. Indian J. Small Rumin. 22, 167169.

DOI: $10.5958 / 0973-9718.2016 .00042 .8$

SAMBROOK, J. E., F. FRITSCH, T. MANIATIS (1989): Molecular Cloning: A Laboratory Manual, $2^{\text {nd }}$ ed. Cold spring Harbor Laboratory Press, New York, USA.

SHIRI, S. A. K., D. A. SAGHI, M. R. NASIRI, H. EMRANI, F. MONTAZER TORBATI, M. MOHAMMADZADE (2006): Survey of genetic diversity growth hormone and growth hormone receptor genes in Iranian indigenous sheep breed (Kordian sheep) using a non-radioactive SSCP. In: Proc. $57^{\text {th }}$ Ann. Meet Europ. Assoc. Anim. Prod. Antalya, Turkey, 21-28.
VALEH, M. V., M. TAHMOORESPOUR, M. ANSARI, M. R. NASSIRY, D. KARIMI, A. TAHERI (2009): Association of growth traits with SSCP polymorphisms at the growth hormone receptor and growth hormone releasing hormone receptor (GHRHR) genes in the Baluchi sheep. J. Anim. Vet. Adv. 8, 1063-1069.

WAKCHAURE, R., S. GANGULY, P. K. PRAVEEN, A. KUMAR, S. SHARMA (2015) Marker assisted selection (mas) in animal breeding: a review. J. Drug. Metab. Toxicol. 6, e127. DOI: $10.4172 / 2157-7609.1000 \mathrm{e} 127$

YE, S., S. DHILLON, X. KE, A. R. COLLINS, I. N. M. DAY (2001): An efficient procedure for genotyping single nucleotide polymorphisms. Nucleic Acids Res. 29, 88.

DOI: $10.1093 /$ nar/29.17.e88

ZHANG, H., Z. WANG, S. WANG, H. LI (2012): Progress of genome-wide association study in domestic animals. J. Anim. Sci. Biotechnol. 3, 1-10.

DOI: $10.1186 / 2049-1891-3-26$

SAHU, A. R., V. JEICHITRA, R. RAJENDRAN, A. RAJA: Povezanost između novih SNP-a u egzonu 10 gena receptora hormona rasta i pokazatelja rasta u indijskih pasmina ovaca. Vet. arhiv 90, 593-602, 2020.

\section{SAŽETAK}

Gen receptora hormona rasta (GHR) kodira tip I citokinskog receptora koji pomaže u vezanju hormona rasta na ovaj receptor, promovirajući dimerizaciju receptora i time regulirajući rast. Ovčji gen GHR, lociran na kromosomu 16, sadržava 10 egzona i 9 introna s netranslatirajućim regijama s obje strane, tvoreći ukupnu veličinu od 178,09 kb. Dosadašnja istraživanja pokazala su da se polimorfizam nalazi većinom u egzonu 10, koji je ujedno veći fragment ovoga gena i sadržava 1102 bp. Ovo je istraživanje provedeno kako bi se otkrio polimorfizam u egzonu 10 gena GHR i njegova povezanost s pokazateljima rasta. Genomska DNA izolirana je iz uzoraka krvi ovaca pasmina Madras Red i Mecheri iz Indije. Dio egzona 10 (895 bp) gena GHR je umnožen i poslan na sekvenciranje koje je u obje pasmine ovaca pokazalo tranziciju nukleotida G > A na lokusima G177624A i G177878A. Probir populacija učinjen je pomoću Tetra-primer ARMS-PCR-a. Učestalost genotipa GG bila je 0,276, genotipa GA 0,519, a genotipa AA 0,205 na 177624 $\mathrm{G}>\mathrm{A}$, te 0,307, 0,444 i 0,149 na $177878 \mathrm{G}>\mathrm{A}$ u pasmine Madras Red. U pasmine Mecheri učestalost genotipa GG bila je 0,476, učestalost genotipa GA 0,372, a genotipa AA 0,152 na $177624 \mathrm{G}>\mathrm{A}$, te $0,629,0,314$ i 0,057 na $177878 \mathrm{G}$ $>$ A. Učestalost alela G i A, koja je bila 0,5355 i 0,4645 na $177624 \mathrm{G}>\mathrm{A}$, te 0,5790 i 0,4210 na $177878 \mathrm{G}>\mathrm{A}$ u ovaca Madras Red, dok je u pasmine Mecheri bila 0,6620 i 0,3380 na 177624 G>A, te 0,7860 i 0,2140 na 177878 G $>$ A. Spol je znakovito utjecao na tjelesnu masu pri janjenju te u dobi od 6 i 9 mjeseci, no nije bilo znakovitog utjecaja u dobi od 3 i 12 mjeseci u pasmine Mecheri. S druge strane, u pasmine Madras Red spol je znakovito utjecao na tjelesnu masu u svim fazama rasta osim pri odbiću. Analizirana je povezanost varijacija s tjelesnom masom pri janjenju, odbiću te u dobi od 6, 9 i 12 mjeseci u obje pasmine, koja nije bila znakovita. Budući da su otkrića ovih SNP-a važna u proučavanju gena GHR u indijskih pasmina ovaca, potrebna su daljnja istraživanja njihova učinka koja bi mogla biti korisna u genetskom poboljšanju populaciju primjenom markerima potpomognute selekcije.

Ključne riječi: povezanost; tjelesna masa; genski receptor hormona rasta; izvorne pasmine ovaca; SNP 